\title{
Euroson 2013 Stuttgart
}

EFSUMB's årlige møde, Euroson, blev afholdt fra den 9. til d. 12. oktober i Stuttgart, som for mange først og fremmest er kendt som sydtysk bilmetropol. Euroson var i år slået sammen med DEGUM Dreiländertreff, dvs. de tysktalende landes ul-

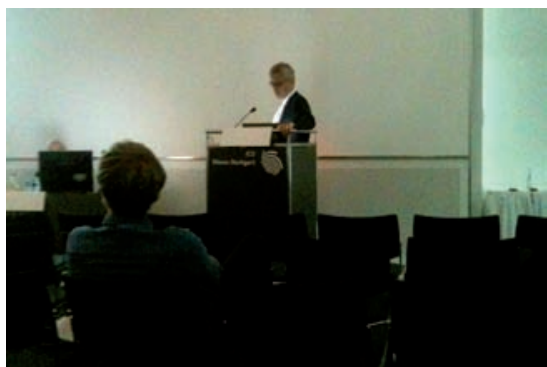

Fig. 1 Professor Jørgen Arendt Jensen til Hans Henrik Holm forelæsningen

tralydselskabers årsmøde. Dette betød, at antallet af deltagere og oplæg var ganske omfattende, samt at der var stor tilslutning af firmaer ved producenternes udstilling. Da DEGUM normalt foregår på tysk, blev en del af sessionerne afholdt på tysk, mens hovedparten foregik på engelsk.

Jeg selv var med som DUDS' repræsentant ved Young Investigator-konkurrencen, hvor i alt 12 yngre forskere fra de forskellige landes ultralydselskaber konkurrerede om at lave den bedste videnskabelige fremlæggelse. Der var mange spændende foredrag på ganske højt niveau i sessionen. Der var blandt andet oplæg om Shearwave-elastografi af leveren ved inflammatorisk tarmsygdom, om transkraniel 3Delastografi af ventrikelsystemet hos nyfødte samt om CEUS rolle ved maligne, non-HCC levertumorer. Mit eget oplæg handlede om strain-elastografi på fantomer. Vinderen i år blev en hollandsk inge- niør, David Maresca, der fortalte om en ny metode, hvormed man med ultralydkontrast og første ordens ultraharmonics kan visualisere mikrovaskulatur i hjertet. Metoden er udviklet med henblik på tidlig diagnostik af neovaskularisering efter pla-

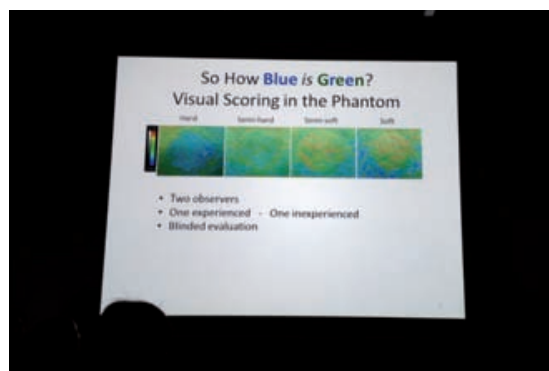

Fig. 2 Titlen på det danske Young Investigator foredrag

quedannelse, idet dette er en af de tidligste prediktorer for fremtidig tromboembolisk sygdom i hjertet.

Både Hans Henrik Holm-forelæsningen og WFUMB's årlige æresforelæsning blev i år holdt af danskere. Professor Jørgen Arendt Jensen (DTU) holdt Hans Henrik Holm-forelæsning om principperne bag vektor flow-skanning, og hvordan det kan bruges i kliniske sammenhænge, mens Overlæge Christian Nolsøe (Herlev Hospital) holdt WFUMB-forelæsning med titlen "Interventional ultrasound - Amazing what you can do with a needle". Begge var meget spændende og inspirerende foredrag. Herudover var Danmark repræsenteret ved flere andre foredragsholdere og chairmen.

Turen indeholdt også et spændende møde med den tyske bilindustri, idet kongresmiddagen på mødets anden dag blev holdt på Mercedes-Benz-museet. Inden middagen var der fri adgang til museet, der består af et imponerende udvalg af biler fra Mercedes-fabrikken. Alt fra de tidligste til de nyeste Mercedes-modeller var udstillet i en spiralgang, der strakte sig over seks etager. Under middagen blev der uddelt priser for bedste poster og bedste

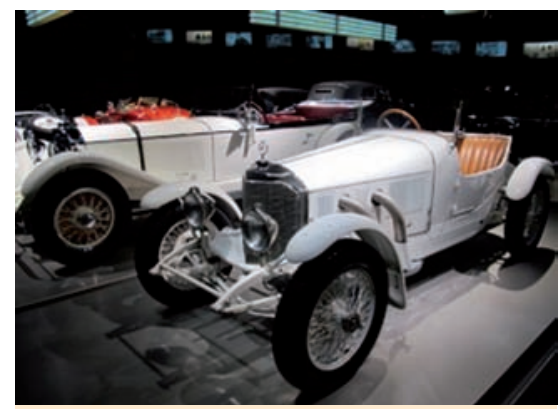

Fig. 3 Mercedes-Benz-museet

præsentation, mens det hele blev rundet af med levende musik og dans.

Afslutningsvis vil jeg gerne sige stor tak til DUDS for støtte til deltagelse ved Euroson 2013.

Læge Jonathan Frederik Carlsen, Rigshospitalet 